\title{
THE MISUNDERSTOOD PERCEPTION IN PRONOUNCING ENGLISH WORDS
}

\author{
Noviana Riahilary1, Yussi Mutia PS², Harum Natasha ${ }^{3}$ \\ State Islamic University of Sultan Syarif Kasim Riau \\ Email: harum.natasha@uin-suska.ac.id
}

\begin{abstract}
Psycholinguistics sides of a language seems to be interesting to be investigated. Thus, this research was aimed at knowing "How students' misunderstood perception in pronouncing English words". Research method is being used in this research is quantitative method. Afterwards this research is described in systematic, factual and accurate about facts or certain object characteristic. This research is executed for 3 weeks: April 28-May 11 2016. The research was conducted at State Islamic University of Sultan Syarif Kasim Riau. The population of the research was all of the students in English Education Department VI I Class with the total number of 25 . Then, in determining the sample the researchers took 10 people by using random sampling. The total number of the sample was 10 students. The instrument used was a questionnaire to measure the students' perception in pronouncing English words that consists of ten questions. The main findings show that most of students have misunderstanding about meaning in English communication.
\end{abstract}

Keywords: Misunderstanding, English communication, Pronunciation

\begin{abstract}
Abstrak
Psikolinguistik dari sisi bahasa tampaknya menarik untuk diteliti. Dengan demikian, penelitian ini bertujuan untuk mengetahui "Bagaimana persepsi salahpaham mahasiswa dalam mengucapkan kata-kata bahasa Inggris". Metode penelitian yang digunakan dalam penelitian ini adalah metode kuantitatif. Selanjutnya, penelitian ini dijelaskan dengan sistematis, faktual dan akurat mengenai fakta-fakta atau karakteristik tertentu dari objek. Penelitian ini dilaksanakan selama 3 minggu: 28 April - 11 Mei 2016. Penelitian dilakukan di Universitas Islam Negeri Sultan Syarif Kasim Riau. Populasi penelitian ini adalah semua mahasiswa di prodi pendidikan bahasa Inggris semester VI Kelas I dengan jumlah total 25. Kemudian, dalam menentukan sampel peneliti mengambil 10 orang dengan menggunakan random sampling. Instrumen yang digunakan adalah kuesioner untuk mengukur persepsi siswa dalam mengucapkan kata-kata bahasa Inggris yang terdiri dari sepuluh pertanyaan. Temuan utama menunjukkan bahwa sebagian besar siswa memiliki kesalahpahaman tentang makna dalam komunikasi bahasa Inggris.
\end{abstract}

Kata Kunci: Kesalahpahaman, komunikasi bahasa Inggris, Pengucapan

\footnotetext{
${ }^{1}$ A student of English Dept at UIN Suska Riau.

${ }^{2}$ A student of English Dept at UIN Suska Riau.

${ }^{3}$ A Lecturer of English Dept at UIN Suska Riau.
} 


\section{INTRODUCTION}

Before someone starts to speak, he needs to hear and recognize the sound first. Communication is a complex human activity that is successful most of the time. This, however, does not mean that understanding is granted or that it is always the case. Misunderstanding is a regular non-extraordinary feature of human interaction, whether communicative interaction is cross-cultural or not. 45

If the communication is verbal, tone of voice can influence interpretation. The boss's words, "Hey, I noticed you were taking an especially long break this morning," could be interpreted as an attack if she or he said that in a disapproving tone, while the comment might be seen as a minor reminder about office rules if it was said in a friendly way. If the employee has a health problem that sometimes requires long breaks, the comment might have even been a friendly inquiry about what was happening and whether the employee needed any help. Here, tone of voice as well as situational and relationship factors would influence the interpretation of the message. Nonverbal cues are also important. All of these factors influence how the same words will be received.

In addition to how the message is sent, many additional factors determine how the receiver interprets the message. All new information we learn is compared with the knowledge we already have. If it confirms what we already know, we will likely receive the new information accurately, though we may pay little attention to it. If it calls into question our previous assumptions or interpretation of the situation, we may distort it in our minds so that it is made to fit our world view, or we may dismiss the information as deceptive, misguided, or simply wrong.

If the message is ambiguous, the receiver is especially likely to clarify it for him or herself in a way which corresponds with his or her expectations. For example, if two people are involved in an escalated conflict, and they each assume that the other is going to be aggressive and hostile, then any ambiguous message will be interpreted as aggressive and hostile, even if it was not intended to be that way at all. Our expectations work as blinders or filters that distort what we see so that it fits our preconceived images of the world.

Common differences are between high-context and low-context communication. Low-context communication stands on its own; it does not require context or interpretation to give it meaning. High-context communication is more ambiguous. It requires background knowledge and understanding (context), in addition to the words themselves, for communication. While everyone uses both kinds of communication, Western cultures tend to use low-context communication more often, while Eastern and Latin American and African

\footnotetext{
${ }^{4}$ Dascal, Marcelo. 1985. “The Relevance of Misunderstanding”, in Marcelo Dascal, ed. Dialogue: An Interdisciplinary Approach, Amsterdam: John Benjamins, P. 441-459

${ }^{5}$ Brown, Gillian. 1995. Speakers, Listeners and Communication, Cambridge: Cambridge University Press, P. 623
} 
cultures tend to use high-context communication. If such differences are not understood and adjusted for, misunderstanding is almost inevitable.

The more someone listens to, the more sounds and vocabularies he get. As a result, the more he can speak and write too. In accordance with the idea above, Nation and Newton ${ }^{6}$ says that listening is a way in learning the language that can help students to build up the knowledge, so after that they can start to speak. From the explanation before, it is clear that listening is a very important skill to learn before the other language skills, i.e. speaking, reading, and writing.

Given our tendency to hear what we expect to hear, it is very easy for people in conflict to misunderstand each other. Communication is already likely to be strained, and people will often want to hide the truth to some extent. Thus the potential for misperception and misunderstanding is high, which can make conflict management or resolution more difficult.

Psycholinguistics is the study of the mental processes and skills underlying the production and comprehension of language, and of the acquisition of these skills. Psycholinguists consider the skilled human language user as a complex informationprocessing system. Their aim is to account for the user's acquisition, production and comprehension of language in terms of the various components of this system and their interactions. Miscommunications, misconceptions and misunderstandings are a common part of everyday human interaction. People, despite their desires to communicate successfully, misunderstand each other's words, silences, gestures or other social actions many often times. Such incidents not only keep happening between interlocutors having different language and culture backgrounds, but also between fellows, spouses, grown-ups and children, medical doctors and their patients, and teachers and their students off and on. Tzanne $^{7}$ suggests that the view that such misunderstandings may have trivial, entertaining, unpleasant and even catastrophic consequences.

Language is a tool of communication, and it becomes important for some reasons. To communicate with other people, we have to use international language. In English courses, there are four skills that must be mastered, and they are writing, speaking, listening and reading. Pronunciation is one of sub-skills in speaking ability. This component acts a very important role in speaking, because by pronouncing English words correctly, students are able to avoid misunderstanding when they speak to other people. Therefore, it is necessary for students to master English pronunciation.

On the other hand, pronunciation is one of the most important parts of English that is used for communication. When a person communicates with other people he should not

\footnotetext{
${ }^{6}$ Nation, I. S. P., \& Newton, J. 2009. Teaching ESL/EFL listening and speaking (First.). New York: Routledge, Taylor \& Francis. P. 38

7 Tzanne, Angeliki. 2000. Talking at Cross-Purposes. Amsterdam: John Benjamins

Publishing Company. P.1
} 
only have a good vocabulary and grammar but also have a good pronunciation. Moreover, being able to communicate correctly and effectively is the goal of all foreign language learners. Without correct pronunciation, however, effective communication does not occur. $\mathrm{Ak}^{8}$ concludes that pronunciation as "the nature of the process to practice listening and speaking by interpreting and producing phonological features respectively". He found that, pronunciation is the process of listening and speaking by interpreting and producing phonological features simultaneously.

Pronunciation is one of the parts of language which is very essential. Nobody could understand the people with poor pronunciation even though their words and grammar are good. In addition, the crashed communication can be caused by the use of incorrect pronunciation. Moreover, being aware of correct pronunciation will give the advantage not only in production, but also the understanding of spoken language. Learning pronunciation is significant to the students in learning English.

It is difficult for Indonesian students to pronounce English words correctly, for example when they are asked to pronounce the word "umbrella" / dmbreld / they will pronounce /umbrella /. It is because of the differences between their mother tongue and English. The degree of difficulty in learning is also determined by the degree of differences between the two languages.

In line with the purpose above, English is much needed to develop the communicative competence, both oral and written form. Furthermore, in order to be able to communicate well in oral communication, the students need to be good in listening and speaking skill, including pronunciation. Moreover, the students continually use listening and speaking to explore, comprehend, and communicate ideas and feelings from early childhood into adulthood. An individual's use of listening and speaking in day-to-day living and learning is much greater than his or her use of, for example, reading and writing.

Based on researchers' preliminary study in State Islamic University of Sultan Syarif Kasim Riau, it is clear that the students do not know how to say and pronounce the English words correctly. The students also still confused to pronounce the words well. In addition, there are some misunderstandings when they communicate to other people. It can be seen from phenomena below:

1. Some of the students are not able to catch the idea in communication;

2. Some of the students are confused how to reply the questions by using English words correctly;

3. Some of students are difficult to understand the English words correctly;

4. Some of students are silent in doing communication;

\footnotetext{
${ }^{8}$ Ak, S. 2012. Pronunciation Awareness Training As An Aid To Developing Efl Learners' Listening Comprehension Skills. Bilken University. P.26.
} 
The weaknesses and the problem above were caused by some factors that come from the students themselves. Based on the background and phenomena above, therefore the researchers were interested to carry out a research entitled "The Misunderstood Perception in Pronouncing English Words"

The researchers formulate the problem in the following research questions:

a. How is the students' misunderstood perception at semester 6 - Class VI I of English Education Department?

b. How is the students' ability in pronouncing English words at semester 6 - Class VI I of English Education Department?

c. How is the students' respond about their misunderstood perception in pronouncing English words at semester 6 - Class VI I of English Education Department?

Based on the formulation of the research above, this research was aimed at finding out 1) the students' misunderstood perception at semester 6 - Class VI I of English Education Department, 2) the students' ability in pronouncing English words at semester 6 -Class VI I of English Education Department, and 3) the students' respond about their misunderstood perception in pronouncing English words at semester 6 - Class VI I of English Education Department.

\section{REVIEWING OF RELATED LITERATURE}

\section{Psycholinguistics}

Psycholinguists study the kinds of representations that are computed by the various processing components (in particular, whether these correspond to representations in linguistic theory), and how these computations are executed in real time.

Psycholinguistics is an integration or overlap of psychology and Linguistics. The field expanded in the 1960s as a response to the intellectual excitement generated by the works of Chomsky. As one of the emerging studies in the field of cognitive science, it studies the mind and mental processes involved in language comprehension (how we perceive and understand speech and written language), production (how we construct an utterance from ideas to completed sentences), and acquisition (how children acquire language)

According to Brown", "Misunderstanding is a regular non-extraordinary feature of human interaction, whether communicative interaction is cross-cultural or not". However, communicative interaction cannot be build without correct pronunciation appears in communicating to other people.

In conversations with others, misunderstandings often arise for various reasons. To avoid misunderstandings and achieve successful communication, speakers and hearers need

\footnotetext{
${ }_{9}^{9}$ Brown, Gillian. 1995. Speakers, Listeners and Communication, Cambridge: Cambridge University Press. P. 623
} 
to achieve some form of mutual understanding. This effort to achieve mutual understanding in communication can, however, go "awry" and may cause misunderstanding.

The misunderstanding may provide amusement, but often causes embarrassment. In an instructional context, however, such misunderstandings may lead to a breakdown in communication and may have a negative impact on the learning experience. Commonly, language is described as the means by which a person learns to organize experiences and thoughts. It stands at the centre of the many cognitive, affective and social factors that shape learning. ${ }^{10}$ One of the most important uses of language, therefore, also in an instructional setting, is for the purposes of successful communication between people, be they native or non-native speakers of the language. ${ }^{11}$ The notion of misunderstanding has been described using socio-linguistic terms, among others, miscommunication, misinterpretation, pragmatic failure or breakdown in communication. ${ }^{12}$

Although one cannot possibly know how often misunderstandings occur in everyday conversation, Dascal ${ }^{13}$ states that it is "assumed that misunderstandings are ubiquitous". Hinnenkamp ${ }^{14}$ agrees by stating that "my own research rather supports the view that misunderstandings are all-pervasive and ubiquitous, in all kind of encounters". This is something we can all agree on as we continuously experience misunderstandings in our everyday lives.

It would seem, however, as if native speakers of English are able to repair misunderstandings rather quickly, often within the next turn. In view of this ability for quick repair, some researchers have come to believe that misunderstandings should not be considered a problem, or something to be fixed, but rather that it should be considered a natural part of communication ${ }^{151617}$. Misunderstandings occur daily, and while these misunderstandings are not necessarily always due to second language (L2) phenomena, such as grammatical inadequacy or cross-cultural transfer, it is evident that second language speakers at times experience difficulties in expressing their thoughts in the target language, which may ultimately result in misunderstanding.

The study of misunderstanding falls within the domain of intercultural communication (ICC). Hinnenkamp ${ }^{18}$ states that misunderstanding has become the "raison -

\footnotetext{
10 Thomas, W. P. and Collier, V. P. A National Study of School Effectiveness for Language Minority Students'Long-term Academic Achievement. (Santa Cruz: CA. Centre for Research on Education, Diversity \& Excellence (CREDE), 2000). P. 335.

${ }^{11}$ Dascal, M. 1999. "Introduction: Some questions about misunderstanding." Journal of Pragmatics. P. 227, 753-754

12 Ibid., P. 753

${ }^{13}$ Opcit., P.754

${ }^{14}$ Hinnenkamp, V. Mixed Language Varieties of Migrant Adolescents and the Discourse of Hybridity, (Journal of Multilingual and Multicultural Development, 2003). P.1-9

${ }^{15}$ Ibid. P.

${ }^{16}$ Wong. Delayed next turn repair initiation in native/non-native speaker English conversation. Applied Linguistics.(2000). P. 226-244

${ }^{17}$ Opcit.

${ }^{18}$ Hinnenkamp. Opcit. P.1
} 
d'etre" for studying ICC because the communication involving the misunderstanding is often between "cultural others". A great body of knowledge on theory and analysis of miscommunications and misunderstandings exists in the literature, mainly perhaps, owing to linguists' interest in ambiguity in language ${ }^{1920212223}$. This research deals with, among others, defining the term "misunderstanding", and classifying and analysing misunderstandings.

However, research interest seems to have excluded the actual misunderstandings that cause miscommunication. Misunderstandings in the literature are generally classified according to structural rather than content factors, such as where the misunderstandings occur in the turn-taking ${ }^{2425}$. There seem to be few classifications that categorise what is actually occurring when misunderstandings take place, and fewer still explain the reasons for the occurrence of misunderstandings in an instructional context, which this study aims to address. The type of misunderstanding and the possible reasons for such misunderstandings could shed light on problematic instructional communication. This study is, therefore, an investigation into the occurrence, type, frequency and causes of misunderstanding in the instructional setting.

\section{Students' Pronunciation}

Our mother tongue has some differences with English in pronunciation. In our language, there is no difference between its writing and its sound. But we find it different in English. Sometimes we sound differently from the writing. For example, the word here is pronounced / hi:d /; however, in Indonesian we pronounce / here /. It is not denied that students often make mistakes in learning foreign language; however, doing such mistake is a part of learning the language itself.

According to Julian Edge on 'Mistakes and Correction' as quoted by Harmer ${ }^{26}$ that mistakes can be divided into three broad categories: 'slips' (that is mistakes which students can correct themselves once the mistake can be pointed out to them), 'errors' (mistakes which they cannot correct themselves - and which therefore need explanation), and 'attempts' (that is when a student tries to say something but not yet know the correct way of saying it). From the three categories, it can be said that error is the most important thing for the teacher to be concerned because the students cannot correct themselves instead of the teacher's help.

There are two kinds of mistakes that might cause the students to make mistake: L1 interference and developmental error. Ramelan ${ }^{27}$ states some reasons about why students make mistake in their pronunciation are because they face such problems as follows:

\footnotetext{
${ }^{19}$ Hinnenkamp. Opcit.

${ }^{20}$ Wong. Opcit.

${ }^{21}$ Dascal. Opcit.

${ }^{22}$ Weigand, Edda, 1999. Misunderstanding: The standard case. Journal of Pragmatics. P. 763-785

${ }^{23}$ Schegloff, Emanuel A., 1987. Some sources of misunderstanding in talk-in-interaction. Linguistics. P.202.

${ }^{24}$ Wong. Opcit.

${ }^{25}$ Schegloff. Ibid.

${ }^{26}$ Harmer, J. 2000. The Practice of English language Teaching. London: Longman Group Ltd. P. 99

${ }^{27}$ Ramelan. 1985. English Phonetics. Semarang: IKIP Semarang Press. P.6-7
} 
a. The existence of a given sound in the latter, which is not found in the former.

b. Sounds which have the same phonetic features in both languages but differ in their distribution.

c. Similar sounds in two languages which differ only slightly in their phonetic features.

d. Sounds that have the same qualities in both languages may constitute some learning problem if they occur in a cluster or sequence of sounds.

\section{Factors that Influence Students' Pronunciation}

Kenworthy in H. Douglas brown in Lizawati Thesis ${ }^{28}$ identifies six factors that influence pronunciation:

a. Native Language

Language will be most influential factor affecting a learners' pronunciation. Native language often interferon on the second language acquisition to pronunciation skill and it might be influenced by the differences of both language.

b. Age

Critical period hypothesis stated that there is time in human development when the brain is predisposed for success in language. The younger age when the learners' begin to acquire English, the better the learner's pronunciation.

c. Exposure

Exposure, in target language can refer to both of the length of time and the intensity of the exposure over time. If class time spent focusing on pronunciation demands the full attention and interest of your student. Then they stand a good chance of reaching their goals.

d. Innate Phonetics Ability

Some people have good ability in phonetics but not in others. Their organ form supports them to pronounce each word correctly. Some people simply have more skill at aptitude for imitating and producing sound and sound pattern that are new to them.

e. Identity and language ego (attitude)

Attitude and Identity have positive relationship to pronunciation ability. Someone who has positive attitude toward English might be able to pronounce English well. Learner's attitude has toward the target language that speakers may affect his or her pronunciation, (the more favorable the attitude, the better the pronunciation, for the highly motivated learner is not opposed to surrounding life target speakers).

\footnotetext{
${ }^{28}$ Lizawati. 2011. The Correlation Between Pronunciation Mastery and Speaking ability at the second year students of Islamic Boarding Senior high School Ittihadul Muslimin Koto Gasib Siak Sri Indrapura. State Islamic University of Sultan Syarif Kasim, Pekanbaru: unpublished
} 
f. Motivation and concern for good pronunciation

The motivation is related to success in learning second language and foreign language. So, this factor is of greatest importance in pronunciation instruction; if learner's motivation to improve is strong and if the investment of time and effort (genuine not reigned) is great, there will be improvement.

\section{Relevant Research}

The relevant research that is taken by the researchers in this research is the research entitled "Misunderstanding in second language instructional communication" by Lizette de Jager, graduated from Education Faculty, University of Pretoria, South Africa 2012. This study was conducted to establish whether misunderstandings occur in an instructional setting and whether they relate to the oral proficiency and communicative competence of student teachers. The analysis of utterances showed that misunderstandings do indeed occur in an instructional setting, and that they can be related to poor oral proficiency.

The second relevant research is a research conducted by Patiricia Bou Franch entitled "Misunderstandings and Unofficial Knowledge in Institutional Discourse". She graduated from Valencia University, Spain on 2002. In her research, she found that misunderstanding is an ordinary aspect of understanding and of interaction in general and to understand it we need to take a transdisciplinary approach. Communication is a complex phenomenon in which cognitive, social, discursive and emotional dimensions are involved. Furthermore, the role of participants' unofficial knowledge of the social requirements of the situation has proved to be central in understanding a sequence of misunderstanding and repair in institutional interaction.

\section{RESEARCH METHODOLOGY}

The participants of the study were 10 students of VI I Class English Education Department, State Islamic University of Sultan Syarif Kasim Riau. In order to get the data, the researchers used questionnaire as the technique of collecting the data. This technique used to find out how is the students' misunderstood perception in pronouncing English words. According to Wilson and McLean in Cohen, Manion, \& Morrison ${ }^{29}$ questionnaire; is a widely used and useful instrument for collecting survey information, providing structured, often numerical data, being able to be administered without the presence of the researchers, and often being comparatively straightforward to analyze. Through questionnaire, the collected data can be processed quickly. In questionnaire, the researchers used 10 items of questionnaire. The questionnaire that the researchers used was based on Likert chart scale. Creswell ${ }^{30}$ stated that there are scoring data that the researchers assign a numeric score

\footnotetext{
${ }^{29}$ Cohen, L., Manion, L., \& Morrison, K. 2007. Research Methods in Education. Education (sixth., Vol. 55). London and New York: Routledge Taylor \& Francis Group. P. 317

${ }^{30}$ Creswell, J. 2012. Educational Research Planning, Conducting and Evaluating Quantitative and Qualitative Research. (P. Smith, Ed.) (fourth edi.). Boston: Pearsin Education, Inc. P. 175.
} 
(value) to each category for each questions on the instrument used to collect data. In the instrument there will be five options for each questions that will be answered by the respondents, they are:

\begin{tabular}{|c|c|c|c|c|}
\hline Always & Usually & Sometimes & Rarely & Never \\
\hline 5 & 4 & 3 & 2 & 1 \\
\hline
\end{tabular}

The questionnaires were distributed to the 10 students which at the time they were given clear instructions and explanation for filling out the questionnaire. The questionnaires were then collected upon completion. The data obtained from the questionnaires were analyzed using the SPSS program. The data concerning subjects' general background as well as their comments were calculated and presented in percentage. A five-point Likert scale was used to measure the level and type of subjects' learning motivation.

\section{FINDINGS AND DISCUSSION}

The data are presented based on the items. In this research, there are 10 items in the questionnaire of students' misunderstood perception in pronouncing English words. They are as follows:

Table 1

I understand what other people talk about in a daily life by using English

\begin{tabular}{|c|c|c|c|}
\hline No & Alternatives & Frequency & Percentage \\
\hline 1 & Always & 3 & $30 \%$ \\
\hline 2 & Usually & 2 & $20 \%$ \\
\hline 3 & Sometimes & 1 & $10 \%$ \\
\hline 4 & Rarely & 3 & $30 \%$ \\
\hline 5 & Never & 1 & $10 \%$ \\
\hline & Total & $\mathbf{1 0}$ & $\mathbf{1 0 0} \%$ \\
\hline
\end{tabular}

Based on the data above, it was found that $30 \%$ of students answered always, $20 \%$ of students answered usually, $10 \%$ of students answered sometimes, $30 \%$ of students answered rarely, and $10 \%$ answered never. It means that, most of students are understand what other people talk about in a daily life by using English.

Table 2

I do not understand what other people talk about in a daily life by using English

\begin{tabular}{|c|c|c|c|}
\hline No & Alternatives & Frequency & Percentage \\
\hline 1 & Always & 1 & $10 \%$ \\
\hline 2 & Usually & 3 & $30 \%$ \\
\hline 3 & Sometimes & 1 & $10 \%$ \\
\hline 4 & Rarely & 2 & $20 \%$ \\
\hline 5 & Never & 3 & $30 \%$ \\
\hline & Total & $\mathbf{1 0}$ & $\mathbf{1 0 0} \%$ \\
\hline
\end{tabular}


Based on the table above, the researchers found that the students who answered always is $10 \%$, the students who answered Usually is $30 \%$, the students who answered Sometimes is $10 \%$, the students who answered rarely is $20 \%$, and the students who answered never is $30 \%$. It can be interpreted that the majority of students are understand what people talk about in a daily life by using English.

Table 3

I understand, but I cannot answer the questions proposed to me by using English

\begin{tabular}{|c|c|c|c|}
\hline No & Alternatives & Frequency & Percentage \\
\hline 1 & Always & 4 & $40 \%$ \\
\hline 2 & Usually & 2 & $20 \%$ \\
\hline 3 & Sometimes & 2 & $20 \%$ \\
\hline 4 & Rarely & 1 & $10 \%$ \\
\hline 5 & Never & 1 & $10 \%$ \\
\hline & Total & $\mathbf{1 0}$ & $\mathbf{1 0 0} \%$ \\
\hline
\end{tabular}

Table 3 shows that $40 \%$ of students answered always, 20\% of students answered usually, $20 \%$ of students answered sometimes, and 10\% of students answered rarely, and $10 \%$ of the students answered never. The percentage indicates that most of students understood, but they cannot reply the questions proposed to me by using English.

Table 4

I can reply the questions proposed to me by using English

\begin{tabular}{|c|c|c|c|}
\hline No & Alternatives & Frequency & Percentage \\
\hline 1 & Always & 2 & $20 \%$ \\
\hline 2 & Usually & 2 & $20 \%$ \\
\hline 3 & Sometimes & 4 & $40 \%$ \\
\hline 4 & Rarely & 2 & $20 \%$ \\
\hline 5 & Never & & \\
\hline & Total & $\mathbf{1 0}$ & $\mathbf{1 0 0} \%$ \\
\hline
\end{tabular}

Based on the table 4 above, it was found that $20 \%$ of students answered always, $20 \%$ of students answered usually, $40 \%$ of students answered sometimes, $20 \%$ of students answered rarely, and $0 \%$ of students answered never. It can be inferred that the majority of students can reply the questions proposed by using English.

Table 5

I can use the expression for asking the interlocutor to repeat the question or statement

\begin{tabular}{|c|c|c|c|}
\hline No & Alternatives & Frequency & Percentage \\
\hline 1 & Always & 3 & $30 \%$ \\
\hline 2 & Usually & 3 & $30 \%$ \\
\hline 3 & Sometimes & 2 & $20 \%$ \\
\hline 4 & Rarely & 1 & $10 \%$ \\
\hline 5 & Never & 1 & $10 \%$ \\
\hline & Total & $\mathbf{1 0}$ & $\mathbf{1 0 0} \%$ \\
\hline
\end{tabular}


The results in table 5 indicate that $30 \%$ of students answered always, $40 \%$ of students answered usually, $20 \%$ of students answered sometimes, $10 \%$ of students answered rarely, and $10 \%$ for never. Thus, it indicates that students can use the expression for asking the interlocutor to repeat the question or statement.

Table 6

I cannot use the expression for asking the interlocutor to repeat the question or statement

\begin{tabular}{|c|c|c|c|}
\hline No & Alternatives & Frequency & Percentage \\
\hline 1 & Always & 1 & $10 \%$ \\
\hline 2 & Usually & 2 & $20 \%$ \\
\hline 3 & Sometimes & 1 & $10 \%$ \\
\hline 4 & Rarely & 3 & $30 \%$ \\
\hline 5 & Never & 3 & $30 \%$ \\
\hline & Total & $\mathbf{1 0}$ & $\mathbf{1 0 0} \%$ \\
\hline
\end{tabular}

Based on the result findings in table 6 , the researchers found that $10 \%$ of students answered always, $20 \%$ of students answered usually, $10 \%$ of students answered sometimes, $30 \%$ of students answered rarely, and $30 \%$ of the students answered never. The result findings indicated students cannot use the expression for asking the interlocutor to repeat the question or statement.

Table 7

I have difficulty in catching the meaning when people speak using their regional dialects.

\begin{tabular}{|c|c|c|c|}
\hline No & Alternatives & Frequency & Percentage \\
\hline 1 & Always & 5 & $50 \%$ \\
\hline 2 & Usually & 3 & $30 \%$ \\
\hline 3 & Sometimes & 1 & $10 \%$ \\
\hline 4 & Rarely & 1 & $10 \%$ \\
\hline 5 & Never & & \\
\hline & Total & $\mathbf{1 0}$ & $\mathbf{1 0 0} \%$ \\
\hline
\end{tabular}

The table 7 reveals that $50 \%$ of students answered always, $30 \%$ of students answered usually, $10 \%$ of students answered sometimes, and $10 \%$ of the students answered rarely, and $0 \%$ of students answered never. It means that the majority of students have difficulty in catching the meaning when people speak using their regional dialects.

Table 8

I cannot understand the word that has similar pronunciation

\begin{tabular}{|c|c|c|c|}
\hline No & Alternatives & Frequency & Percentage \\
\hline 1 & Always & 6 & $60 \%$ \\
\hline 2 & Usually & 2 & $20 \%$ \\
\hline 3 & Sometimes & 1 & $10 \%$ \\
\hline 4 & Rarely & 1 & $10 \%$ \\
\hline 5 & Never & & \\
\hline & Total & $\mathbf{7 2}$ & $\mathbf{1 0 0} \%$ \\
\hline
\end{tabular}


It can be seen that $60 \%$ answered always, 20\% answered usually, $10 \%$ answered sometimes, $10 \%$ answered rarely and $0 \%$ answered never. It means that the majority of the students cannot understand the word that has similar pronunciation.

Table 9

I can understand the word that has similar pronunciation

\begin{tabular}{|c|c|c|c|}
\hline No & Alternatives & Frequency & Percentage \\
\hline 1 & Always & 6 & $60 \%$ \\
\hline 2 & Usually & 2 & $20 \%$ \\
\hline 3 & Sometimes & 1 & $10 \%$ \\
\hline 4 & Rarely & 1 & $10 \%$ \\
\hline 5 & Never & & \\
\hline & Total & $\mathbf{1 0}$ & $\mathbf{1 0 0} \%$ \\
\hline
\end{tabular}

The result findings in table 9, the researchers found that the majority of students frequently even always understand the word that has similar pronunciation. It can be seen from the percentage that $60 \%$ of students answered always, $20 \%$ of students answered usually, $10 \%$ of students answered sometimes, $10 \%$ of students answered rarely and $0 \%$ answered never.

Table 10

At least I communicate to my friends by using English 15 minutes a day

\begin{tabular}{|c|c|c|c|}
\hline No & Alternatives & Frequency & Percentage \\
\hline 1 & Always & 1 & $10 \%$ \\
\hline 2 & Usually & 3 & $30 \%$ \\
\hline 3 & Sometimes & 1 & $10 \%$ \\
\hline 4 & Rarely & 1 & $10 \%$ \\
\hline 5 & Never & 4 & $40 \%$ \\
\hline & Total & $\mathbf{7 2}$ & $\mathbf{1 0 0} \%$ \\
\hline
\end{tabular}

The result findings in table 10 shows that only $10 \%$ of the students answered always, $30 \%$ answered usually, 10\% answered sometimes, 10\% answered rarely, and $40 \%$ of the students answered never. It can be inferred that the majority of students never use English in communicating to other students.

\section{CONCLUSION}

The objective of this research was to find out whether there is a misunderstood perception in English communication or not. Based on the data analysis on the previous explanation, the researchers conclude the result of those analyses became 3 items of conclusions that related to the three research questions. 
The students' misunderstood perception at sixth semester VI I Class of English Education Department is categorized into satisfying level. Eventhough most of them are never to use English in daily conversation, the data has proved that most of them could ignore the misunderstanding in communication among their friends. It was proved by several facts; 1 ) most of the students understand what other people talk about in a daily life by using English, 2) the majority of the students understand what people talk about in a daily life by using English, 3) the percentage indicates that most of students understood, but they cannot answer the questions proposed to the researchers by using English, 4) the majority of the students can reply the questions proposed by using English, 5) students can use the expression for asking the interlocutor to repeat the question or statement, 6) the students cannot use the expression for asking the interlocutor to repeat the question or statement, 7) the majority of the students have difficulty in catching the meaning when people speak using their regional dialects, 8) the majority of the students cannot understand the word that has similar pronunciation, 9) the majority of the students frequently even always understand the word that has similar pronunciation, 10) the majority of the students never use English in communicating to other students. 


\section{REFERENCE}

Ak, S. 2012. Pronunciation Awareness Training As An Aid To Developing Efl Learners' Listening Comprehension Skills. Bilken University.

Brown, Gillian. 1995. Speakers, Listeners and Communication, Cambridge: Cambridge University Press.

Cohen, L., Manion, L., \& Morrison, K. 2007. Research Methods in Education. Education (sixth., Vol. 55). London and New York: Routledge Taylor \& Francis Group.

Creswell, J. 2012. Educational Research Planning, Conducting and Evaluating Quantitative and Qualitative Research. (P. Smith, Ed.) (fourth edi.). Boston: Pearsin Education, Inc.

Dascal, Marcelo. 1985. “The Relevance of Misunderstanding”, in Marcelo Dascal, ed.

Dialogue: An Interdisciplinary Approach, Amsterdam: John Benjamins.

Dascal, M. 1999. "Introduction: Some questions about misunderstanding." Journal of Pragmatics.

Harmer, J. 2000. The Practice of English language Teaching. London: Longman Group Ltd.

Hinnenkamp, V. 2003. Mixed Language Varieties of Migrant Adolescents and the Discourse of Hybridity, Journal of Multilingual and Multicultural Development.

Hornby, A.S. 1995. Oxford Advanced Learners Dictionary. Oxford: Oxford University Press.

Kenworthy, J. 1987. Teaching English pronunciation. London: Longman.

Lizawati. 2011. The Correlation Between Pronunciation Mastery and Speaking ability at the second year students of Islamic Boarding Senior high School Ittihadul Muslimin Koto Gasib Siak Sri Indrapura. State Islamic University of Sultan Syarif Kasim, Pekanbaru: unpublished

Nation, I. S. P., \& Newton, J. 2009. Teaching ESL/EFL listening and speaking (First.). New York: Routledge, Taylor \& Francis.

Ramelan. 1985. English Phonetics. Semarang: IKIP Semarang Press.

Schegloff, Emanuel A., 1987. Some sources of misunderstanding in talk-in-interaction. Linguistics.

Thomas, W. P. and Collier, V. P. 2000. A National Study of School Effectiveness for Language Minority Students'Long-term Academic Achievement. Santa Cruz, CA. Centre for Research on Education, Diversity \& Excellence (CREDE).

Tzanne, Angeliki. 2000. Talking at Cross-Purposes. Amsterdam: John Benjamins Publishing Company.

Weigand, Edda, 1999. Misunderstanding: The standard case. Journal of Pragmatics.

Weizman, Elda, 1999. Building True Understanding via Apparent Miscommunication: A Case Study. Journal of Pragmatics.

Wong, J. 2000. Delayed next turn repair initiation in native/non-native speaker English conversation. Applied Linguistics. 
142 Tazkir Vol. 02 No. 1 Januari-Juni 2016

ULAMA BERBAGI OTORITAS:

Fungsi dan Peran MUI Kota Padanmgsidimpuan

Dalam Meningkatkan Kesadaran dan Budaya Hukum Masyarakat 